\title{
Travel Health Survey: Risk Perception, Health-Seeking Behavior, and Subjective Evaluation of Travel Health Services in Egypt
}

\author{
Engy Mohamed El-Ghitany ${ }^{1 *}$, Mohamed Abdelsalam Mohamed Abdelmohsen ${ }^{1}$, Azza Galal Farghaly ${ }^{1}$, \\ Ensaf Saied Abd El-Gawwad ${ }^{2}$, Ekram Wassim Abd El-Wahab'
}

${ }^{1}$ Tropical Health Department, High Institute of Public Health, Alexandria University, Alexandria, Egypt

${ }^{2}$ Health Education and Behavioral Science Department, High Institute of Public Health, Alexandria University, Alexandria, Egypt

Corresponding Author: Engy Mohamed El-Ghitany, Dr.PH, MPH, DTM\&H, Professor, Tropical Health Department, High Institute of Public Health, Alexandria University, Egypt. Tel: +2-01001781333, Fax: +2-03-5457037, Email: ingy.elghitany@gmail.com

Received January 11, 2018; Accepted January 30, 2018; Online Published February 18, 2018

\begin{abstract}
Introduction: Travel health practice and research in Egypt lag behind both needs and demands. This study was done in two parts to assess travel health knowledge, attitude, and practice (KAP) among Egyptian travelers.

Methods: This survey was conducted at the departure halls of Cairo International Airport and included 1500 travelers to Africa (excluding North Africa), Southeast Asia, and Latin America. An interview questionnaire was used to measure the KAP of travelers inquiring about different aspects of pre-travel health. Subjective evaluations of travel health services and suggestions for improvement were also solicited. Results: Travelers in this study were mainly males (89.3\%), less than 40 years of age (82\%), living in urban residences $(89.1 \%)$, married $(65.9 \%)$, university educated (83.3\%), traveling for work (69.1\%) with destinations of Africa (61.3\%), Asia (28.4\%), and Latin America (10.3\%). They had poor travel-associated risk perception, and only $13.4 \%$ had risk management plan. Less than half (42.4\%) sought information about their destination, and $11.9 \%$ sought health information; their source of information was mainly the internet (98.7\%). The majority had poor scores on various travel-related practices, including seeking pre-travel health services $(87.9 \%)$, receiving pre-travel vaccines $(91.3 \%)$, and using malaria chemoprophylaxis (90.6\%). The travel health services were rated good by $0.5 \%$ of travelers and bad, very bad, or undetermined by $11.4 \%, 61.3 \%$, and $26.9 \%$ respectively.

Conclusion: Egyptian travelers, although mostly educated, had poor travel health perceptions and practices and are unsatisfied with the travel health services in Egypt.

Keywords: Travel Medicine, Egypt, Surveys and Questionnaires
\end{abstract}

Citation: El-Ghitany EM, Mohamed Abdelmohsen MA, Farghaly AG, Abd El-Gawwad ES, Abd El- Wahab EW. Travel health survey: risk perception, health-seeking behavior, and subjective evaluation of travel health services in Egypt. Int J Travel Med Glob Health. 2018;6(1):16-24. doi:10.15171/ ijtmgh.2018.04.

\section{Introduction}

International civilian travel globally has experienced continued growth and expansion since the advent of modern commercial aviation in the 1950s and over the past 6 decades. ${ }^{1}$

The number of departures from Egypt was 4863000 in 2014. The inbound and outbound tourism segments witnessed positive growth in 2014, despite the sluggish growth during the global downturn. ${ }^{2}$ Outbound travel recovered swiftly in 2011 as many Egyptians who could afford to do so left the country because of the instability. The number of departures was predicted to increase at an average annual rate of $3 \% .^{3}$

Since the 1990s, the number of scientific articles on travel medicine has increased almost threefold compared to the preceding decades, implicating the increase in the importance of and attention given by the medical profession to this discipline of infectious diseases. ${ }^{4}$

Many studies have highlighted the underutilization of pretravel health advice, the lack of knowledge regarding travel medicine, and the large number of travelers that are unaware of the health risks abroad. ${ }^{5,6}$

The European Travel Health Advisory Board (ETHAB) utilized a knowledge, attitude, and practice (KAP) survey to assess the KAP associated with travel health. The ETHAB's study highlighted a lack of knowledge among travelers, even experienced ones, and the poor utilization of the preventive measures. ${ }^{5}$

Copyright (C) 2018 The Author(s). This is an open-access article distributed under the terms of the Creative Commons Attribution License (http:// creativecommons.org/licenses/by/4.0), which permits unrestricted use, distribution, and reproduction in any medium, provided the original work is properly cited. 
Several consecutive studies investigated the KAP of travelers. Most of them used the standardized questionnaire developed by ETHAB. Almost all of these studies were conducted at international airports in various countries of the world. ${ }^{7-9}$

The travel health practice and research in Egypt lag behind both needs and demands. Almost nothing is known about where Egyptian travelers get their travel health knowledge, how they perceive the health risks of travel, or what measures are taken to avoid potential risks. Therefore, this study was done in two parts to assess travel health KAP among Egyptian travelers. In this first part, the current travel health-seeking behavior, risk perception, different pre-travel practices and satisfaction and evaluation of the adequacy of pre-travel health services are described and evaluated.

\section{Methods}

This study was conducted at the departure halls of Cairo International Airport. Inclusion criteria included being an Egyptian traveler, at least 18 years of age, and having a final destination of Africa, Southeast Asia, or Latin America. Passengers to North Africa were excluded from the study.

Using a power of $80 \%$ to detect a significant level of health knowledge among travelers $=23.1 \%,{ }^{10}$ alpha error $=5 \%$, with a precision of $3 \%$, the minimal required sample size was calculated by Epi-Info software to be 756. Because no data for Egyptian travelers was available, it was assumed that Egyptians are less knowledgeable about travel health than Asians (a selected close reference), and the sample size was expanded to 1500 travelers.

The study design was a cross-sectional interview survey using face-to-face interviews.

\section{Study Procedure}

Development of the questionnaire: An interview questionnaire that measures the KAP of travelers was developed through an internet-based literature search on worldwide KAP studies, guided by the ETHAB standardized questionnaire, ${ }^{11}$ and frequent meetings of the authors.

The questionnaire included 71 questions, 48 of which inquired about socio-demographic data, previous travel history, current journey details, perception of travelassociated risks, presence of risks management plans, details about the received pre-travel health services, and travel health-information seeking behavior. A subjective evaluation of travel health services and suggestions for improvement were also solicited. The remaining questions were related to vaccinations and malaria chemoprophylaxis and are discussed in the second part of this study.

\section{Pilot Study}

A pilot testing of the questionnaire was carried out from January to October, 2014, at Alexandria Fever Hospital. The questionnaire was tested on 50 individuals among those being evaluated for blood-borne viral infections (HCV, HBV, and HIV) as a prerequisite for traveling to gulf countries. Accordingly, questionnaire modifications were made including rephrasing and adding or removing some questions.
Data Collection

Data collection continued from November 2014 to October 2015. Passengers were selected using the simple random sampling technique. The time spent for interviewing each participant ranged between 35 to 45 minutes; thus, the researcher was able to interview 10-15 travelers daily.

\section{Statistical Analysis}

Data were fed to the computer and analyzed using IBM SPSS software package version 20.0. Categorical data were presented in frequencies. Quantitative data were described using mean/ median and standard deviation. The Kolmogorov-Smirnov test was used to test normality of data. The Mann-Whitney test was used for non-parametric quantitative variables to compare between two groups, while the Kruskal-Wallis test was used when more than two groups were compared. Spearman coefficient was used to correlate between 2 nonparametric quantitative variables. Significance of the obtained results was judged at the $5 \%$ level.

A score for perception of travel associated risks was developed by assigning a score of 0 for the answer "not exposed to any risk" and a score of 1 for each possible risk answer, giving a maximum total score of 23. The scores of perceived travel-associated risks were leveled as follows:

- Low level of perception of travel associated risks (0-7)

- Medium level of perception of travel associated risks (815)

- High level of perception of travel associated risks (16-23) A scoring system was also established for each of the travel health-related practices, including risk management plan, carrying protective measures, seeking pre-travel health services and information, receiving vaccines, using malaria prophylaxis, and intent to use prophylactic measures. A Likert-like scale was applied where a score of 0 was given for no or incorrect practices and the highest score was given to the best practice. The total sum of scores for each parameter was grouped into three ranked categories. The lowest was referred to as (poor), the middle was referred to as (fair), and the highest was referred to as (good).

\section{Results}

The socio-demographic description of participating travelers is shown in Table 1 . The majority of them (78.5\%) had no reported chronic medical condition. The distribution of the travelers according to the current journey details is illustrated in Table 2. Africa was the destination for $61.3 \%$ of travelers, while Asia accounted for $28.5 \%$.

Almost half of the participants $(658 ; 43.9 \%)$ had a history of previous travel with destinations of Africa (51.8\%), Asia (46.5\%), Europe (14\%), North America (5.6\%), South and Central America (0.9\% each), and Australia (0.5\%). Only 224 (34\%) of the studied travelers with a history of traveling abroad stated that they had received any vaccination before their previous travels, including meningococcal (59\%), yellow fever $(55.4 \%)$, influenza (1.3\%), cholera (0.9\%), HAV (0.4\%), and HBV $(0.4 \%)$ vaccines. Regarding prior travel-associated health problems, diarrhea was the most encountered health problem among travelers (39.5\%), followed by ear problems 
Table 1. Distribution of the Travelers at Cairo International Airport According to Their Socio-Demographic Characteristics

\begin{tabular}{|c|c|}
\hline Socio-Demographics Characteristics $(n=1500)$ & No. $(\%)$ \\
\hline \multicolumn{2}{|l|}{ Gender } \\
\hline Male & $1340(89.3)$ \\
\hline Female & $160(10.7)$ \\
\hline \multicolumn{2}{|l|}{ Age $(y)$} \\
\hline$<30$ & $538(35.9)$ \\
\hline 30 to $<40$ & $691(46.1)$ \\
\hline+40 & $271(18.1)$ \\
\hline Min - Max & $18.0-78.0$ \\
\hline Mean \pm SD & $\begin{array}{c}33.10 \pm \\
7.117\end{array}$ \\
\hline \multicolumn{2}{|l|}{ Residency } \\
\hline Rural & $163(10.9)$ \\
\hline Urban & $1337(89.1)$ \\
\hline \multicolumn{2}{|l|}{ City of residency } \\
\hline Cairo & $534(35.6)$ \\
\hline Al-Giza & $276(18.4)$ \\
\hline Alexandria & $172(11.5)$ \\
\hline Al-Beheira & $106(7.1)$ \\
\hline Kafr-Elsheikh & $61(4.1)$ \\
\hline Al-Qaliobeya & $85(5.7)$ \\
\hline Al-Daqahlia & $55(3.7)$ \\
\hline Al-Gharabia & $30(2.0)$ \\
\hline Al-Fayuom & $13(0.9)$ \\
\hline Damietta & $6(0.4)$ \\
\hline Al-Menoufeya & $14(0.9)$ \\
\hline AL-Sharqeya & $33(2.2)$ \\
\hline Canal cities (Suez, Port Said, Ismaeleya) & $59(3.9)$ \\
\hline Upper Egypt cities (Assuit, Beny Suef, Elmenia, Sohaj, Qenna) & $56(3.7)$ \\
\hline \multicolumn{2}{|l|}{ Marital status } \\
\hline Single & $510(34.0)$ \\
\hline Married & $988(65.9)$ \\
\hline Widowed & $2(0.1)$ \\
\hline \multicolumn{2}{|l|}{ Presence of offspring } \\
\hline No & $713(47.5)$ \\
\hline Yes & $787(52.5)$ \\
\hline \multicolumn{2}{|l|}{ Number of family members } \\
\hline $2-<5$ & $891(59.4)$ \\
\hline $5-9$ & $609(40.6)$ \\
\hline Min-Max & $2.0-9.0$ \\
\hline Mean \pm SD & $4.28 \pm 1.58$ \\
\hline \multicolumn{2}{|l|}{ Occupation } \\
\hline Housewife & $40(2.7)$ \\
\hline Professional (professor, researcher, teacher, lawyer, etc) & $570(38.0)$ \\
\hline Employee & $150(10.0)$ \\
\hline Worker (labor, guard, etc) & $66(4.4)$ \\
\hline Artisanal work (carpenter, smith, plumber, painter, etc) & $188(12.5)$ \\
\hline Athlete & $152(10.1)$ \\
\hline Religion man & $115(7.7)$ \\
\hline Healthcare worker (doctor, nurse, pharmacist, etc) & $123(8.2)$ \\
\hline Tradesman & $85(5.7)$ \\
\hline Others (not working, student, military persons) & $11(0.7)$ \\
\hline \multicolumn{2}{|l|}{ Level of education } \\
\hline Illiterate & $9(0.6)$ \\
\hline Less than 9 years education & $81(5.4)$ \\
\hline Secondary & $160(10.7)$ \\
\hline University education and post graduate & $1250(83.3)$ \\
\hline \multicolumn{2}{|l|}{ Type of education, $(n=1410)$} \\
\hline Literature & $419(29.7)$ \\
\hline Scientific & $867(61.5)$ \\
\hline Medical & $124(8.8)$ \\
\hline \multicolumn{2}{|l|}{ Monthly income } \\
\hline Not enough & $416(27.7)$ \\
\hline Enough & $1073(71.5)$ \\
\hline Enough and saving & $11(0.7)$ \\
\hline
\end{tabular}

Table 2. Distribution of the Travelers at Cairo International Airport According to the Journey Details

\begin{tabular}{|c|c|}
\hline Journey details $(n=1500)$ & No. $(\%)$ \\
\hline \multicolumn{2}{|l|}{ Travel destination (country and city) } \\
\hline East Africa & $211(14.1)$ \\
\hline Central Africa & $285(19.0)$ \\
\hline West Africa & $254(16.9)$ \\
\hline Southern Africa & $169(11.3)$ \\
\hline South East Asia & $221(14.7)$ \\
\hline South Asia & $125(8.3)$ \\
\hline Asia Others & $81(5.4)$ \\
\hline North Latin America & $25(1.7)$ \\
\hline Central Latin America & $41(2.7)$ \\
\hline South Latin America & $88(5.9)$ \\
\hline \multicolumn{2}{|l|}{ Type of destination (rural/urban) } \\
\hline Urban & $1279(85.3)$ \\
\hline Rural & $1(0.1)$ \\
\hline Do not know & $220(14.7)$ \\
\hline \multicolumn{2}{|l|}{ Altitude of destination } \\
\hline Do not know & $689(45.9)$ \\
\hline High & $51(3.4)$ \\
\hline Sea level & $760(50.7)$ \\
\hline \multicolumn{2}{|l|}{ Type of accommodation in destination } \\
\hline Hotel & $641(42.7)$ \\
\hline Private house & $790(52.7)$ \\
\hline Youth hostel & $23(1.5)$ \\
\hline $\begin{array}{l}\text { Others (residency in a factory, residency in a hospital, } \\
\text { worship places) }\end{array}$ & $46(3.1)$ \\
\hline \multicolumn{2}{|l|}{ Purpose of travel } \\
\hline Tourism & $176(11.7)$ \\
\hline Work & $1037(69.1)$ \\
\hline Study & $3(0.2)$ \\
\hline Seeking medical treatment & $4(0.3)$ \\
\hline Sports & $140(9.3)$ \\
\hline Others** & $140(9.3)$ \\
\hline Length of stay in days, Mean \pm SD & $115.97 \pm 118.748$ \\
\hline \multicolumn{2}{|l|}{ Presence of companions* } \\
\hline No & $295(19.7)$ \\
\hline Spouse & 312 (20.8) \\
\hline Offspring & $163(10.9)$ \\
\hline Relatives & $37(2.5)$ \\
\hline Friends & $47(3.1$ \\
\hline Work colleagues & $845(56.3)$ \\
\hline Others (parents) & $3(0.2)$ \\
\hline \multicolumn{2}{|l|}{ Duration between journey planning and date of travel } \\
\hline Two weeks or less & $85(5.7)$ \\
\hline Three weeks & $81(5.4)$ \\
\hline 1 month & $579(38.6)$ \\
\hline More than 1 month & $755(50.3)$ \\
\hline
\end{tabular}

*Multiple response question

**Others = Accompanying parents or husband, visiting relatives, attending conference, making a movie, Qur'an memorization competition, relief committee, traditional arts competition.

Central Africa (Sudan, South Sudan, Chad, Niger, Central Africa, and Congo), West Africa (Mali, Mauritania, Senegal, Gambia, Sierra Leone, Liberia, Cote d'Ivoire, Burkina Faso, Ghana, Benin, Togo, Nigeria, Cameroon, Equatorial Guinea, and Gabon), East Africa (Tanzania, Kenya, Uganda, Rwanda, Burundi, Djibouti, Eretria, Ethiopia, Somalia, Seychelles, and Union of Comoros), Southern Africa (Mozambique, Madagascar, Malawi, Zambia, Angola, Namibia, and Botswana), Southeast Asia (Thailand, Malaysia, Indonesia, Singapore, Philippines, Cambodia, Brunei, Vietnam, and Burma), South Asia (Sri Lanka, India, Bangladesh, and Pakistan), other Asian countries (Yemen, Oman, and South Korea), North Latin America (Mexico), Central Latin America (Bahamas, Cuba, Honduras, Haiti, Jamaica, Puerto Rico, Panama, Salvador, and Nicaragua), South Latin America (Brazil, Venezuela, Bolivia, Argentina, Paraguay, Peru, Colombia, and Ecuador). 


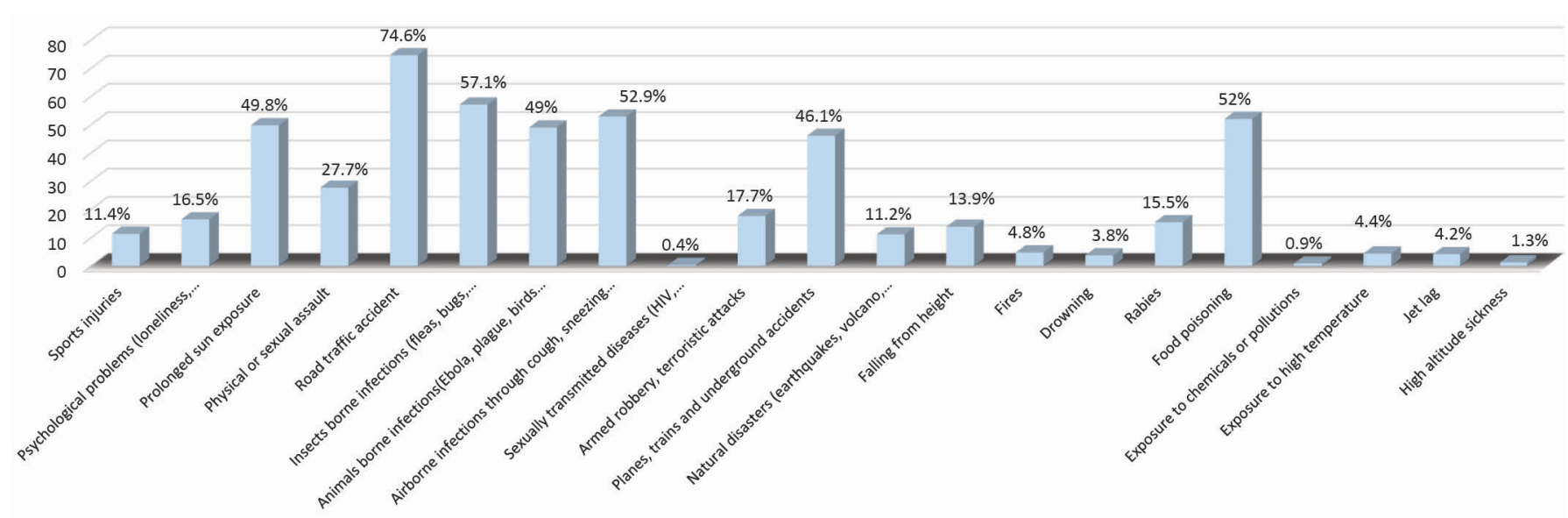

Figure 1. Types of Risks at Destination for Travelers Who Perceived any Travel Health-Related Risks.

Table 3. Distribution of Travelers at Cairo International Airport According to Travel Risk Management Plans

\begin{tabular}{|c|c|c|}
\hline Travel Risk Management Plans $(n=1500)$ & No. & $\%$ \\
\hline \multicolumn{3}{|l|}{ Presence of risk plan for potential risks } \\
\hline Not perceiving risks & 713 & 47.5 \\
\hline No risk management plan & 586 & 39.1 \\
\hline Yes, for most of them & 86 & 5.7 \\
\hline Yes, for some of them & 115 & 7.7 \\
\hline \multicolumn{3}{|l|}{ Infection control measures $(\mathrm{n}=175)^{*}$} \\
\hline Food, drink sanitation & 166 & 94.9 \\
\hline Vaccination & 87 & 49.7 \\
\hline Masks & 19 & 10.9 \\
\hline \multicolumn{3}{|l|}{ Sports injuries preventive measures $(n=53)^{*}$} \\
\hline Sports shoes & 51 & 96.2 \\
\hline Helmets & 0 & 0.0 \\
\hline Safety belt & 4 & 7.5 \\
\hline First aid bag & 6 & 11.3 \\
\hline \multicolumn{3}{|c|}{ Occupational accidents preventive measures $(n=19) *$} \\
\hline Protective clothing & 2 & 10.5 \\
\hline Helmets & 18 & 94.7 \\
\hline Earpieces & 1 & 5.3 \\
\hline Antislip shoes & 1 & 5.3 \\
\hline \multicolumn{3}{|c|}{ Violence accidents preventive measures $(n=98)^{*}$} \\
\hline Commitment to organized program & 69 & 70.4 \\
\hline Commitment to laws & 55 & 56.1 \\
\hline Car seat belt & 23 & 23.5 \\
\hline \multicolumn{3}{|l|}{ Healthy lifestyle measures $(n=146)^{*}$} \\
\hline Personal hygiene measures & 105 & 71.9 \\
\hline Safety rules & 11 & 7.5 \\
\hline Not exposed to sun for long periods & 98 & 67.1 \\
\hline \multicolumn{3}{|l|}{ Carrying protective measures $(n=455)^{*}$} \\
\hline Antidiarrheal drugs & 161 & 35.4 \\
\hline Antiallergy drugs & 79 & 17.4 \\
\hline Antibiotics & 178 & 39.1 \\
\hline Drugs for chronic diseases & 120 & 26.4 \\
\hline Malaria chemoprophylaxis & 137 & 30.1 \\
\hline Mosquito repellents & 12 & 2.6 \\
\hline Sunscreens & 24 & 5.3 \\
\hline Helmets & 1 & 0.2 \\
\hline Special clothes or shoes & 46 & 10.1 \\
\hline Other** & 36 & 7.9 \\
\hline \multicolumn{3}{|c|}{ Requirement of special health certificate for the country of destination } \\
\hline Do not know & 600 & 40.0 \\
\hline No & 899 & 59.9 \\
\hline Yes & 1 & 0.1 \\
\hline
\end{tabular}

*Multiple response question; **Others= Antipyretics and ear drops.
(19.6\%) and less frequently fever (7.9\%), dizziness (7.9\%), syncope (3.8\%), insomnia (3.6\%), jet lag (3.5\%), and highaltitude sickness $(0.8 \%)$. On the other hand, about one third $(33.6 \%)$ of travelers did not declare any previous post-travel health conditions.

About half of the travelers (47.5\%) did not perceive any travel-associated risks. The frequencies of various risk perception are illustrated in Figure 1, and the distribution of travelers according to their travel risks management plan is presented in Table 3.

The mean total score of perceived travel-associated risks was low (2.7). The differences in total score of travelassociated risks perception according to various travelers and travel-related factors are shown in Table 4.

Only $12.1 \%$ of travelers sought pre-travel health services, and the mean time between travel and obtaining health services was $1.74 \pm 4.8$ days. Two main sources for pretravel health services were mentioned by travelers, namely governmental hospitals and malaria prophylaxis centers (40.7\% and $78.6 \%$, respectively). About $30.8 \%$ sought pretravel health services in traveler's vaccination centers and $13.7 \%$ in private hospitals. Only one traveler sought services in a private clinic.

The health services received by travelers were mainly vaccinations and prophylactic drugs $(70.9 \%$ and $78.6 \%$, respectively). Other health services included health education $(1.1 \%)$, laboratory investigations $(1.1 \%)$, and radiological investigations $(0.5 \%)$. General medical examinations were obtained by $14.3 \%$ of them.

Seeking pre-travel health services was significantly higher among travelers above the age of 40 years $(19.2 \%, P<0.001)$. There was no gender or residence predilection for seeking pre-travel health services. Moreover, this practice did not differ significantly among experienced and first-time travelers $(11.1 \%$ vs. $12.9 \%$, respectively) or by the time of trip preparation. However, it was significantly higher among travelers traveling for seeking medical treatment $(P<0.001)$.

Regarding the feasibility of obtaining pre-travel health services, $73.6 \%$ stated that it was difficult to get pre-travel health services due to distance and inaccessibility (46.7\%), lack of specialized travel clinics (33\%), overcrowding (16.5\%), 
Table 4. Mean (SD) and Median of Studied Travelers' Total Score of Perceived Travel-Associated Risks by Some Socio-demographic and Travel Characteristics

\begin{tabular}{|c|c|c|c|c|c|c|}
\hline \multirow{2}{*}{ Socio-demographic and Travel Characteristics } & \multicolumn{4}{|c|}{ Perception of TravelAssociated Risks Total Score ${ }^{a}$} & \multirow{2}{*}{ Test of Sig. } & \multirow{2}{*}{$P$} \\
\hline & No. & Mean & \pm SD & Median & & \\
\hline \multicolumn{7}{|l|}{ Gender } \\
\hline Male & 1340 & 2.82 & 2.9 & 2.0 & \multirow[t]{2}{*}{$z=4.493^{*}$} & \multirow[t]{2}{*}{$<0.001^{*}$} \\
\hline Female & 160 & 1.69 & 2.4 & 0.0 & & \\
\hline \multicolumn{7}{|l|}{ Age (y) } \\
\hline$<30$ & 538 & 3.0 & 2.87 & 3.0 & \multirow{3}{*}{$\mathrm{kW}^{2}=24.774^{*}$} & \multirow{3}{*}{$<0.001^{*}$} \\
\hline 30 to $<40$ & 691 & 2.73 & 2.98 & 2.0 & & \\
\hline $40+$ & 271 & 2.01 & 2.84 & 0.0 & & \\
\hline \multicolumn{7}{|l|}{ Residency } \\
\hline Rural & 163 & 3.15 & 2.97 & 4.0 & \multirow{2}{*}{$z=2.031^{*}$} & \multirow{2}{*}{$0.042^{*}$} \\
\hline Urban & 1337 & 2.64 & 2.93 & 1.0 & & \\
\hline \multicolumn{7}{|l|}{ Marital status } \\
\hline Not married & 512 & 3.26 & 2.87 & 4.0 & \multirow{2}{*}{$z=6.038^{*}$} & \multirow{2}{*}{$<0.001^{*}$} \\
\hline Married & 988 & 2.40 & 2.93 & 0.0 & & \\
\hline \multicolumn{7}{|l|}{ Education level } \\
\hline Illiterate & 9 & 4.0 & 3.16 & 5.0 & \multirow{4}{*}{${ }^{\mathrm{kW}} \mathrm{X}^{2}=29.110^{*}$} & \multirow{4}{*}{$<0.001^{*}$} \\
\hline Less than 9 years education & 81 & 3.92 & 2.97 & 5.0 & & \\
\hline Secondary & 160 & 3.42 & 2.93 & 4.0 & & \\
\hline University and postgraduate education & 1250 & 2.52 & 2.90 & 0.0 & & \\
\hline \multicolumn{7}{|l|}{ Education type } \\
\hline Literature & 419 & 2.25 & 2.66 & 0.0 & \multirow{3}{*}{$\mathrm{kw}^{2}=16.407^{*}$} & \multirow{3}{*}{$<0.001^{*}$} \\
\hline Scientific & 867 & 2.65 & 2.94 & 1.0 & & \\
\hline Medical & 124 & 3.63 & 3.32 & 4.0 & & \\
\hline Monthly income & & & & & & \\
\hline Not enough & 416 & 3.65 & 3.03 & 4.0 & & \\
\hline Enough & 1073 & 2.34 & 2.82 & 0.0 & ${ }^{\mathrm{kW}} \mathrm{X}^{2}=57.728^{*}$ & $<0.001^{*}$ \\
\hline Enough and saving & 11.0 & 1.82 & 2.23 & 0.0 & & \\
\hline Medical history & & & & & & \\
\hline No & 1178 & 2.72 & 2.89 & 2.0 & $7=1079$ & 0280 \\
\hline Yes & 322 & 2.61 & 3.11 & 0.0 & $2-1.073$ & 0.200 \\
\hline Previous travels & & & & & & \\
\hline No & 842 & 3.48 & 2.98 & 4.0 & $7=11685^{*}$ & $<0.001^{*}$ \\
\hline Yes & 658 & 1.69 & 2.54 & 0.0 & $2-11.003$ & $<0.001$ \\
\hline Destination & & & & & & \\
\hline Africa & 919 & 2.98 & 3.01 & 3.0 & & \\
\hline Asia & 427 & 2.21 & 2.81 & 0.0 & ${ }^{\mathrm{kW}} \mathrm{X}^{2}=24.752^{*}$ & $<0.001^{*}$ \\
\hline America & 154 & 2.35 & 2.64 & 0.0 & & \\
\hline Purpose of travel & & & & & & \\
\hline Tourism & 176 & 2.34 & 2.85 & 0.0 & & \\
\hline Work & 1037 & 2.83 & 3.02 & 2.0 & & \\
\hline Study & 3 & 2.67 & 3.06 & 2.0 & $k W_{y^{2}}-5268$ & 0384 \\
\hline Seeking medical treatment & 4 & 3.0 & 3.46 & 3.0 & $\mathrm{x}-3.200$ & 0.507 \\
\hline Sports & 140 & 2.33 & 2.21 & 2.0 & & \\
\hline Other** & 140 & 2.56 & 3.03 & 0.0 & & \\
\hline Presence of health insurance & & & & & & \\
\hline No & 1152 & 2.82 & 2.96 & 2.0 & $7=3124^{*}$ & $0.002^{*}$ \\
\hline Yes & 348 & 2.27 & 2.81 & 0.0 & $2-5.124$ & \\
\hline
\end{tabular}

Abbreviation: SD, Standard Deviation; KW, Kruskal Wallis test for comparing between the different studied groups; z, z value for Mann-Whitney test.

*Statistically significant; ** Others = Accompanying parents or husband, visiting relatives, attending conference, making a movie, Quran memorization competition, relief committee, traditional arts competition; ${ }^{a}$ Travel's associated risks total score range (0-23).

high cost $(1.6 \%)$, or lengthy routine procedures $(0.5 \%)$. Less than half of the studied travelers sought any information before travel; health information accounted for only $11.9 \%$ of the general information sought by travelers. The type of information, barriers, sources, and degrees of satisfaction are detailed in Table 5.

Travel health-related practices were described in general as poor. The details are illustrated in Table 6.
Inquiries into the travelers' opinions of the quality of travel health services resulted in $61.3 \%$ of travelers stating that the quality of travel health services is very poor and only $0.5 \%$ stating that it is of good quality. Their suggestions to improve services are listed in Table 7.

\section{Discussion}

Unlike most European travelers among whom travelers to 
Table 5. Distribution of Travelers at Cairo International Airport According to Travel Health-Seeking Information

\begin{tabular}{|c|c|c|}
\hline Travel Information $(n=1500)$ & No. & $\%$ \\
\hline \multicolumn{3}{|l|}{ Seeking any information about destination } \\
\hline No & 864 & 57.6 \\
\hline Yes & 636 & 42.4 \\
\hline \multicolumn{3}{|l|}{ Type of general information sought $(n=636)^{*}$} \\
\hline Weather & 552 & 86.8 \\
\hline Altitude & 120 & 18.9 \\
\hline Rural or urban & 102 & 16.0 \\
\hline Lifestyles & 158 & 27.8 \\
\hline Prices & 515 & 81.0 \\
\hline Crowding & 87 & 13.7 \\
\hline Transportation & 388 & 61.0 \\
\hline Entertainment places & 225 & 35.4 \\
\hline Crime rates & 56 & 8.8 \\
\hline Health information & 76 & 11.9 \\
\hline Other** & 42 & 6.6 \\
\hline \multicolumn{3}{|l|}{ Type of health information sought $(n=76)^{*}$} \\
\hline Prevalent diseases & 32 & 42.1 \\
\hline Mode of transmission of these diseases & 3 & 3.9 \\
\hline Preventive measures for these diseases & 8 & 10.5 \\
\hline Therapeutic modalities for these diseases & 3 & 3.9 \\
\hline Required vaccination & 66 & 86.8 \\
\hline \multicolumn{3}{|l|}{ Perceived barriers for not seeking health information $(n=1424)^{*}$} \\
\hline Scarcity of time & 241 & 16.9 \\
\hline It is not necessary & 217 & 15.2 \\
\hline I will know what I need there & 306 & 21.5 \\
\hline I depend on companions & 243 & 17.1 \\
\hline $\begin{array}{l}\text { I am not susceptible as I received the preventive } \\
\text { measures }\end{array}$ & 89 & 6.3 \\
\hline $\begin{array}{l}\text { I do not know that there are health risks associated with } \\
\text { travel }\end{array}$ & 878 & 61.7 \\
\hline \multicolumn{3}{|l|}{ Sources of pretravel health information $(n=76)^{*}$} \\
\hline Travel agency & 3 & 3.9 \\
\hline Tourism offices & 1 & 1.3 \\
\hline Family & 4 & 5.3 \\
\hline Friends, work colleagues & 30 & 39.5 \\
\hline Specialized physician & 4 & 5.3 \\
\hline Pharmacist & 3 & 3.9 \\
\hline Internet & 75 & 98.7 \\
\hline Embassy & 3 & 3.9 \\
\hline Other & 1 & 1.3 \\
\hline \multicolumn{3}{|l|}{$\begin{array}{l}\text { Degree of satisfaction with received pretravel health } \\
\text { information. }(n=76)^{*}\end{array}$} \\
\hline Not satisfied at all & 16 & 21.1 \\
\hline Not satisfied & 38 & 50.0 \\
\hline Satisfied & 21 & 27.6 \\
\hline Extremely satisfied & 1 & 1.3 \\
\hline
\end{tabular}

* Multiple response question; $* *$ Other $=$ Hotels, shopping places, political information, residential places, life expenses, recreational activities, libraries and museums.

tropical countries are usually above the age of 40 years and travel mostly for leisure, ${ }^{12}$ travelers from less developed countries ${ }^{13}$ including Egypt are young, and their main purpose of travel is for work. This reflects the importance of keeping this productive and active group healthy.

Diarrhea was the most frequent health problem among experienced travelers, having a percentage similar to that found by other studies. ${ }^{14-16}$ Ear problems represented the second most frequent health problem (one-fifth), which were related mainly to changes in air pressure inside the plane itself rather than being caused by injury or infection acquired at destinations. ${ }^{17}$ A similar figure (19\%) was reported among travelers on a South American expedition. ${ }^{18}$ None of the experienced travelers in this study reported respiratory infection in their previous travels, and this result disagrees with many studies reporting respiratory infections as a major travel health-associated problem. ${ }^{19,20}$ However, this may be attributed to recall bias or low perceived importance of the flu/common cold as a respiratory disease. Only $7.9 \%$ of experienced travelers mentioned fever as a travel-associated problem. Likewise, in Italy, fever accounted for $7 \%$ of health problems in travelers returning from the tropics. ${ }^{21}$ Fever represented $26 \%$ and $29 \%$ of travel-associated problems in the GeoSentinel surveillance and in German travelers destined to tropical and subtropical zones, respectively. ${ }^{22,23}$ Only one third of the present study participants claimed they did not encounter any health problems in their previous travels compared to $74 \%$ of American travelers, which could be attributed to better pre-travel health services and awareness in the latter group. ${ }^{24}$

Only $34 \%$ of experienced travelers had received pretravel vaccinations comprised mainly of required or highly recommended vaccines, namely the meningococcal vaccine received by travelers to KSA for pilgrimages and the yellow fever vaccine received by travelers to Africa which represented the most frequent previous travel destination (51.8\%).

The perceived health risk in the current survey was poor and reflected the absence of a risk management plan for most travelers. Moreover, less than one third of the participants were carrying protective measures. The situation was different in other studies in Spain ${ }^{25}$ and Peru, ${ }^{13}$ where $91.2 \%$ and $47.3 \%$ of travelers, respectively, were carrying medications.

Risk perception is a very important safeguard for selfprotection. ${ }^{26}$ This was higher among the younger age group ( $<30$ years) despite their poor travel health-related knowledge and poor practices. This might be attributed to more apprehension or more concern about the risks and temptations of traveling, which could compel travelers to express more positive attitudes about various hazards in destinations.

Moreover, there was higher perception of travel risks among illiterate travelers, despite having less knowledge about travel-associated risks. This can be explained by hidden fears and the inability to cope with stress and risks. ${ }^{27}$ Education provides better opportunities and skills to deal with risks, and that might decrease one's perception of endangering risks. However, gender, age, destination, and region-related travel experience had different impacts on the travelers' risk perception. ${ }^{28}$ Having an older age and a higher level of education were predictors of increased travel risk perception in $\mathrm{KSA}^{29}$ and Qatar. ${ }^{30}$

Only $12.1 \%$ of travelers sought pre-travel health services, although $83.3 \%$ were well educated, $89.1 \%$ were urban residents, $72 \%$ had a satisfactory income, and $43.9 \%$ had a previous travel history. This was far lower than what was reported in South African (86\%), ${ }^{31}$ Spanish (83.1\%), ${ }^{25}$ European (40\%), ${ }^{12}$ American (36\%), ${ }^{32}$ Australian (32\%), ${ }^{9}$ 
Table 6. Distribution of Travelers at Cairo International Airport According to Level of Travel Health-Related Practices

\begin{tabular}{|c|c|c|c|c|c|c|}
\hline \multirow{3}{*}{ Traveler Practices } & \multicolumn{6}{|c|}{ Level of Practices Score $(n=1500)$} \\
\hline & \multicolumn{2}{|c|}{ Poor $<50 \%$} & \multicolumn{2}{|c|}{ Fair $50 \%-75 \%$} & \multicolumn{2}{|c|}{ Good $75 \%+$} \\
\hline & No. & $\%$ & No. & $\%$ & No. & $\%$ \\
\hline Preparing risk management plan & 1299 & 86.6 & 115 & 7.7 & 86 & 5.7 \\
\hline Detailed risk management plan & 1468 & 97.9 & 32 & 2.1 & 0 & 0.0 \\
\hline Carrying protective measures & 1056 & 70.4 & 353 & 23.5 & 91 & 6.1 \\
\hline Seeking pre-travel health services & 1318 & 87.9 & 0 & 0.0 & 182 & 12.1 \\
\hline Seeking information about destination & 864 & 57.6 & 0 & 0.0 & 636 & 42.4 \\
\hline Received pre-travel vaccines & 1370 & 91.3 & 0 & 0.0 & 130 & 8.7 \\
\hline Use of malaria chemoprophylaxis & 1359 & 90.6 & 0 & 0.0 & 141 & 9.4 \\
\hline Use of malaria chemoprophylaxis as required (right timing) & 1356 & 90.4 & 47 & 3.1 & 97 & 6.5 \\
\hline Intent to use prophylactic measures & 995 & 66.3 & 427 & 28.5 & 78 & 5.2 \\
\hline
\end{tabular}

Table 7. Distribution of Travelers at Cairo International Airport According to Evaluation of Travel Health Service and Suggestions About Travel Health

\begin{tabular}{|c|c|c|}
\hline Evaluation of Travel Health Service and Suggestions About Travel Health $(n=1500)$ & No. & $\%$ \\
\hline \multicolumn{3}{|l|}{ Opinion about the quality of travel health services } \\
\hline Very bad & 919 & 61.3 \\
\hline Bad & 171 & 11.4 \\
\hline Undetermined & 403 & 26.9 \\
\hline Good & 7 & 0.5 \\
\hline Very good & 0 & 0.0 \\
\hline I do not know & 625 & 41.7 \\
\hline Decline to answer & 272 & 18.1 \\
\hline Suggestions related to travel heath education and public health awareness & 313 & 20.9 \\
\hline Suggestions related to access to travel heath service & 356 & 23.7 \\
\hline Suggestions related to vaccination and malaria chemoprophylaxis & 47 & 3.1 \\
\hline \multicolumn{3}{|l|}{ Traveler's suggestions about the information they would like to receive before traveling* } \\
\hline I do not know & 345 & 23.0 \\
\hline Destination's climate & 103 & 6.9 \\
\hline Transportation in destination county & 77 & 5.1 \\
\hline Ways of communication & 82 & 5.5 \\
\hline Safety and security & 90 & 6.0 \\
\hline Economic aspects & 255 & 17.0 \\
\hline Religious issues & 39 & 2.6 \\
\hline Tourism information & 190 & 12.7 \\
\hline Culture and language & 34 & 2.3 \\
\hline Information about sanitation & 26 & 1.7 \\
\hline Information related to malaria & 54 & 3.6 \\
\hline Information related to other diseases & 587 & 39.1 \\
\hline Miscellaneous issues & 163 & 10.9 \\
\hline
\end{tabular}

* Multiple response question.

Dubaian (22.8\%), ${ }^{33}$ and Qatari (19\%), ${ }^{30}$ travelers.

Moreover, in the present study, only $11.9 \%$ of travelers sought health information about their destination. This explains in part the low risk awareness and perception. LaRocque et $\mathrm{al}^{34}$ found that $46 \%$ of international travelers in Australia did not pursue health information of any type; a lack of concern about health problems related to the trip was the most commonly cited reason, and this was also the case in the current study.

The internet proved to be the most popular source for health information for more Egyptian travelers (98.6\%) than for Japanese $(64.1 \%),{ }^{35}$ European $(24 \%),{ }^{12}$ or US travelers $(19 \%){ }^{32}$ This reflects the unavailability of professional travel health services, and it can be anticipated that the information was unsatisfactory and the quality may vary greatly between and within sources. ${ }^{12}$

Ideally, travelers should seek medical advice at least 4-6 weeks before departure. An important factor for inadequate pre-travel-seeking behavior was reported to be the increasing number of last minute travelers who planned their trips in less than 2 weeks. ${ }^{6,33}$

Conversely in the current study, although the majority of travelers had enough time to plan their travel (3 weeks or more), $85 \%$ and $93.1 \%$ of those who had planned their trip more than one month prior to their trip did not seek pretravel health services or health information, respectively, and 
the mean time for obtaining health services before travel for those who did was too short (1.74 \pm 4.8 days).

Egyptian travel health services were not satisfactory, as most participants reported them as very bad and one quarter were neutral, unlike elsewhere ${ }^{9,33}$ where satisfaction was highly rated.

A high proportion of travelers would like to have information about diseases in their destinations (39.1\%), even though $61.7 \%$ of them did not know that there are diseases associated with travel. However, some travelers may have been sensitized by the interview questionnaire which may have made them more curious about the importance of getting health information and services before traveling.

\section{Conclusion}

Egyptian travelers to tropical areas are usually young educated males traveling for work. They generally have a poor perception of travel-associated health risks and do not have a risk management plan. Travel health awareness is poor regardless of age, education, or any other socio-demographic factor. A minority of travelers seek health information before traveling, and the internet is their main source of information. Their pre-travel practices are poor, and only one eighth seek any pre-travel services. The travel health services in Egypt were evaluated by the travelers as poor and must be improved.

\section{Authors' Contributions}

Study conception and design: EGEM; Acquisition of data: AMAM, AEWEW; Analysis and interpretation of data: EGEM, FAG, AEGES, AEWEW, AMAM; Drafting of manuscript: EG EM, AMAM, AEWEW; Critical revision: EGEM , FAG, AEGES, AEWEW.

\section{Conflicts of Interest Disclosures}

None.

\section{Ethical Approval}

The study strictly followed the ethical guidelines of the Helsinki Declaration and was approved by the High Institute of Public Health Ethics Committee. Participation of travelers was voluntarily and a written informed consent was obtained from each participant.

\section{Funding/Support}

None.

\section{References}

1. World Tourism Organization (UNWTO). Global report on Aviation: Responding to the needs of new tourism markets and destinations. Madrid: World Tourism Organization; 2012:76.

2. The World Bank Group. Indicators 2010. The World Bank; 2015. http://data.worldbank.org/indicator/. Accessed Sep 15, 2016.

3. Euro Monitor International. Travel and tourism in Egypt. Euro Monitor International; 2016. http://www.euromonitor.com/tourismflows-outbound-in-egypt/report. Accessed Oct 20, 2016.

4. Hill DR, Ericsson CD, Pearson RD, et al. The practice of travel medicine: guidelines by the Infectious Diseases Society of America. Clin Infect Dis. 2006;43(12):1499-1539. doi:10.1086/508782.

5. Hamer DH, Connor BA. Travel health knowledge, attitudes and practices among United States travelers. J Travel Med.
Research Highlights

What Is Already Known?

Almost nothing is known about travel health knowledge and practices in Egypt.

\section{What This Study Adds?}

This study represents baseline data describing all travel health-related aspects in Egypt. The important data provided by this article includes but is not restricted to the following:

1. Sociodemographic data is given on travelers, their destinations, reasons for and duration of travel and reflects the importance of providing sound travel health awareness and practices in Egypt.

2. This is the first study in Egypt to develop a scoring system for knowledge, risk perception, and practice.

3. The questionnaire was comprehensive and described all travel medicine-related areas of KAP among Egyptians.

4. The study highlights how the KAP of this field of medicine are deficient in Egypt and the alarming and urgent need to improve.

2004;11(1):23-26. doi:10.2310/7060.2004.13577.

6. Van Herck K, Zuckerman J, Castelli F, Van Damme P, Walker E, Steffen R. Travelers' knowledge, attitudes, and practices on prevention of infectious diseases: results from a pilot study. J Travel Med. 2003;10(2):75-78. doi:10.2310/7060.2003.31638.

7. van Genderen PJ, van Thiel PP, Mulder PG, Overbosch D. Trends in knowledge, attitudes, and practices of travel risk groups toward prevention of hepatitis A: results from the Dutch Schiphol Airport survey 2002 to 2009. J Travel Med. 2012;19(1):35-43. doi:10.1111/ j.1708-8305.2011.00578.x.

8. Pistone T, Guibert P, Gay F, et al. Malaria risk perception, knowledge and prophylaxis practices among travellers of African ethnicity living in Paris and visiting their country of origin in sub-Saharan Africa. Trans R Soc Trop Med Hyg. 2007;101(10):990-995. doi:10.1016/j. trstmh.2007.05.009.

9. Wilder-Smith A, Khairullah NS, Song JH, Chen CY, Torresi J. Travel health knowledge, attitudes and practices among Australasian travelers. J Travel Med. 2004;11(1):9-15. doi:10.2310/7060.2004.13600.

10. Machin D, Campbell MJ, Tan SB, Tan SH. Sample size tables for clinical studies. 3rd ed. London, UK: Blackwell Scientific Publishing; 2009:253.

11. Zuckerman J. Shaping travel health and medicine for the future. Lancet Infect Dis. 2001;1(5):296-297. doi:10.1016/s14733099(01)00142-6.

12. Van Herck K, Van Damme P, Castelli F, et al. Knowledge, attitudes and practices in travel-related infectious diseases: the European airport survey. JTravel Med. 2004;11(1):3-8. doi:10.2310/7060.2004.13609.

13. Cabada MM, Maldonado F, Quispe W, et al. Pretravel health advice among international travelers visiting Cuzco, Peru. J Travel Med. 2005;12(2):61-65. doi:10.2310/7060.2005.12201.

14. Greenwood Z, Black J, Weld L, et al. Gastrointestinal infection among international travelers globally. J Travel Med. 2008;15(4):221228. doi:10.1111/j.1708-8305.2008.00203.x.

15. Centers for Disease Control and Prevention. Travelers' diarrhea. CDC; 2016. https://wwwnc.cdc.gov/travel/yellowbook/2018/thepre-travel-consultation/travelers-diarrhea. Accessed Feb 9, 2016.

16. Mizuno Y, Kudo K. Travel-related health problems in Japanese travelers. Travel Med Infect Dis. 2009;7(5):296-300. doi:10.1016/j. tmaid.2009.03.002.

17. American Academy of Otolaryngology. Ears and altitude. Entnet 
2013. http://www.entnet.org/HealthInformation/earsAltitude.cfm. Accessed Dec 16, 2016

18. Shaw MT, Leggat PA. Life and death on the Amazon: illness and injury to travelers on a South American expedition. J Travel Med. 2003;10(5):268-271. doi:10.2310/7060.2003.2694.

19. Camps M, Vilella A, Marcos MA, et al. Incidence of respiratory viruses among travelers with a febrile syndrome returning from tropical and subtropical areas. J Med Virol. 2008;80(4):711-715. doi:10.1002/jmv.21086

20. Leder K, Sundararajan V, Weld L, Pandey P, Brown G, Torresi J. Respiratory tract infections in travelers: a review of the GeoSentinel surveillance network. Clin Infect Dis. 2003;36(4):399-406. doi:10.1086/346155.

21. Antinori S, Galimberti L, Gianelli E, et al. Prospective observational study of fever in hospitalized returning travelers and migrants from tropical areas, 1997-2001. J Travel Med. 2004;11(3):135-142. doi:10.2310/7060.2004.18557.

22. Herbinger $\mathrm{KH}$, Alberer $\mathrm{M}$, Berens-Riha $\mathrm{N}$, et al. Spectrum of Imported Infectious Diseases: A Comparative Prevalence Study of 16,817 German Travelers and 977 Immigrants from the Tropics and Subtropics. Am J Trop Med Hyg. 2016;94(4):757-766. doi:10.4269/ ajtmh.15-0731.

23. Leder K, Torresi J, Libman MD, et al. GeoSentinel surveillance of illness in returned travelers, 2007-2011. Ann Intern Med. 2013;158(6):456-468. doi:10.7326/0003-4819-158-6-20130319000005 .

24. Hill DR. Health problems in a large cohort of Americans traveling to developing countries. J Travel Med. 2000;7(5):259-266. doi:10.2310/7060.2000.00075

25. Lopez-Velez R, Bayas JM. Spanish travelers to high-risk areas in the tropics: airport survey of travel health knowledge, attitudes, and practices in vaccination and malaria prevention. J Travel Med. 2007;14(5):297-305. doi:10.1111/j.1708-8305.2007.00142.x.

26. Chen CM, Tsai JS, Chen SH, Lee HT. Knowledge, attitudes, and practices concerning infection control among travelers between Taiwan and mainland China. Asia Pac J Public Health. 2011;23(5):712-720. doi:10.1177/1010539511419118.

27. Yoo YJ, Bae GO, Choi JH, et al. Korean travelers' knowledge, attitudes, and practices regarding the prevention of malaria: measures taken by travelers departing for India from Incheon International Airport. J Travel Med. 2007;14(6):381-385. doi:10.1111/j.17088305.2007.00157.x.

28. Zimmermann R, Hattendorf J, Blum J, Nuesch R, Hatz C. Risk perception of travelers to tropical and subtropical countries visiting a swiss travel health center. J Travel Med. 2013;20(1):3-10. doi:10.1111/j.1708-8305.2012.00671.x.

29. Alghamdi A, Ibrahim A, S Al-Ghamdi M, T Ryan E, Al-Raddadi R. Travel Health in the Kingdom of Saudi Arabia: Perception and Practice of Saudi Travelers. Int J Health Res Innov. 2014;2(2):25-39.

30. Al-Hajri MM. Traveler's preventive health measures against infectious diseases and physicians' awareness toward travel medicine in Qatar 2007 [dissertation]. Qatar: Arab Board in Community; 2008.

31. Toovey S, Jamieson A, Holloway M. Travelers' knowledge, attitudes and practices on the prevention of infectious diseases: results from a study at Johannesburg International Airport. J Travel Med. 2004;11(1):16-22. doi:10.2310/7060.2004.13587.

32. Hamer DH, Connor BA. Travel health knowledge, attitudes and practices among United States travelers. J Travel Med. 2004;11(1):2326. doi:10.2310/7060.2004.13577.

33. Omer F, Hassan N, Hussain H, Mana S, Awad O. Travel health, gaps in knowledge, attitudes, and practices among Dubai travellers, Dubai UAE. Int J Prev Med Res. 2015;1(3):126-131.

34. LaRocque RC, Rao SR, Tsibris A, et al. Travel health knowledge, attitudes and practices among Australian travelers. J Travel Med. 2010;17(6):386-390.

35. Namikawa K, lida T, Ouchi K, Kimura M. Knowledge, attitudes, and practices of Japanese travelers on infectious disease risks and immunization uptake. J Travel Med. 2010;17(3):171-175. doi:10.1111/j.1708-8305.2010.00405.x. 